\title{
PEMANFAATAN VIDEO SEBAGAI MEDIA PEMBELAJARAN UNTUK MENINGKATKAN MINAT BELAJAR DAN HASIL BELAJAR SISWA PADA MATA PELAJARAN MENGGAMBAR TEKNIK DASAR KELAS X PROGRAM KEAHLIAN KONSTRUKSI BATU DAN BETON SMK NEGERI 2 PEMATANGSIANTAR
}

\author{
Oriza Sipayung1, Darwin ${ }^{2}$ \\ ${ }^{1}$ Alumni Program Studi Pendidikan Teknik Bangunan, Fakultas Teknik UNIMED \\ ${ }^{2}$ Dosen Pengajar Jurusan Pendidikan Teknik Bangunan, Fakultas Teknik UNIMED \\ (Darwin@gmail.com)
}

\begin{abstract}
ABSTRAK
Tujuan dari penelitian ini adalah untuk meningkatkan minat belajar dan hasil belajar pada mata pelajaran Menggambar Teknik Dasar Siswa Kelas X Program Keahlian Konstruksi Batu Dan Beton SMK Negeri 2 Pematangsiantar dengan menerapkan Pemanfaatan Video Sebagai Media Pembelajaran. Penelitian ini merupakan penelitian tindakan kelas yang dilakukan pada semester ganjil tahun ajaran 2015/2016 dengan jumlah siswa 34 orang. Berdasarkan hasil evaluasi dan kriteria keberhasilan yang telah ditetapkan dalam penelitian ini ditemukan siklus I nilai rata-rata minat belajar siswa meningkat yaitu 63,09 menjadi 82,50 pada siklus II. Sedangkan nilai rata-rata hasil belajar siswa siklus I meningkat yaitu 72 ketercapaian kelas 64\% menjadi 85 ketercapaian kelas 75\% pada siklus II. Hasil penelitian menunjukkan penerapan Pemanfaatan Video Sebagai Media Pembelajaran dapat meningkatkan minat belajar dan hasil belajar siswa pada mata pelajaran Menggambar Teknik Dasar.
\end{abstract}

Kata Kunci : Media Pembelajaran Video, Minat Belajar dan Hasil Belajar

\begin{abstract}
The purpose of this research is to improve the activated and outcomes learning in subject Science Statics Building Student Class X Programe Expertise Of Engineering Picture Building SMKN Binaan By Applying The Type Learning Start With A Question. This research is a classroom action research conducted in the second semester of academic year 2015/2016 with the number of students are 22 people. Based on the evaluation and success criteria that have been established of this research, found the first cycle the average value of activated student increase 67,23 become 87,88 on the second cycle. While the average value of the outcames learning on the first cycle increase that 69,06 achievement of class $64 \%$ become 87,88 achievement of class $75 \%$ on the second cycle. The result showed the application of Type Learning Start With A Question mode can improve activated and outcomes learning of student in subject Science Statics Building.
\end{abstract}

Keywords: Learning Start With A Question, Activated And Outcames Learning 


\section{Pendahuluan}

Pendidikan merupakan masalah yang penting bagi manusia, karena menyangkut kelangsungan hidup manusia dan tingkat kecerdasan bangsa.Manusia tidak cukup hanya tumbuh dan berkembang dengan dorongan alamiah saja, tetapi perlu pendidikan.Pendidikan merupakan salah satu alternatif untuk meningkatkan sumber daya manusia yang tangguh. Dengan pendidikan dan ilmu pengetahuan manusia dapat mengembangkan dirinya, sehingga dapat mengatasi dan memenuhi kebutuhan hidup yang semakin kompleks. Pendidikan sangat penting dan tidak dapat dipisahkan dengan kehidupan, baik seseorang, keluarga, masyarakat, dan bangsa.

Sekolah Menengah Kejuruan (SMK) merupakan salah satu subsistem dari Sistem Pendidikan Nasional mempunyai fungsi untuk membentuk manusia pembangunan yang bermoral Pancasila. Dan secara lebih khusus lagi pada GBPP (Kurikulum SMK edisi 2004:7) dijelaskan bahwa tujuan SMK sebagai bagian dari sistem Pendidikan Menengah dalam Pendidikan Nasional mempunyai tujuan sebagai berikut : (1) Menyiapkan siswa menjadi manusia produktif, mampu bekerja mandiri, mengisi lowongan pekerjaan yang ada di dunia usaha dan dunia industri sebagai tenaga kerja tingkat menengah sesuai dengan kompetensi dalam program keahlian yang dipilihnya. (2) Menyiapkan siswa agar mampu memilih karier, ulet dan gigih dalam berkompetensi, beradaptasi di lingkungan kerja, dan mengembangkan sikap profesional dalam bidang keahlian yang diminatinya. (3) membekali siswa dengan ilmu pengetahuan, teknologi dan seni, agar mampu mengembangkan diri dikemudian hari baik secara mandiri maupun melalui jenjang pendidikan yang lebih tinggi. (4) Membekali siswa dengan kompetensi-kompetensi yang sesuai dengan program keahlian yang dipilih.

Namun lembaga pendidikan SMK khususnya di Indonesia memiliki permasalahan yang sering timbul dapat diindikasikan dengan permasalahan belajar dari siswa dalam memahami materi. Indikasi ini dimungkinkan karena faktor belajar siswa yang kurang efektif, bahkan siswa sendiri tidak merasa berminat didalam mengikuti pembelajaran di kelas. Sehingga menyebabkan siswa kurang atau bahkan tidak memahami materi yang diberikan oleh guru.
Dari hasil observasi yang dilakukan peneliti di kelas $\mathrm{x}$ program keahlian batu beton SMK Negeri 2 Pematangsiantar pada tanggal 23 Juli 2015, melalui pengamatan peneliti di kelas dan wawancara dengan Drs. Esman Hutasoit selaku guru yang mengajar di kelas $\mathrm{X}$ program keahlian konstruksi batu dan beton, ditemukan permasalahan bahwa dalam pembelajaran dikelas minat siswa masih rendah. Hal ini dapat dilihat dari minat siswa dalam mempersiapkan buku pelajaran, mengerjakan tugas, menjawab pertanyaan, dan memperhatikan pelajaran masih sangat rendah dan nilai siswa kelas $X$ Program Keahlian Teknik Gambar Bangunan di SMK Negeri 2 Pematangsiantar tahun ajaran 2012/2013 adalah 75,12, pada tahun ajaran 2013/2014 nilai rata-ratanya adalah 70,40 , dan pada Tahun Ajaran 2014/2015, nilai rata-rata mata diklat menggambar teknik dasar siswa adalah 75 . Itu artinya nilai yang dicapai siswa sudah mencapai Kriteria Ketuntasan Minimal (KKM) yaitu $\geq 70$.

Hal ini disebabkan karena terjadinya sebuah masalah dalam proses belajar mengajar, dimana setelah melakukan observasi dapat dilihat masalah yang terjadi yaitu: rendahnya minat belajar dan hasil belajar Menggambar Teknik Dasar siswa. Oleh karena hal tersebut, peneliti berupaya untuk meningkatkan minat belajar dan hasil belajar siswa dengan menerapkan pemanfaatan video sebagai media pembelajaran.

Rumusan masalah penelitian ini adalah : (1) Apakah pemanfaatan video sebagai media pembelajaran dapat meningkatkan minat belajarsiswa pada mata pelajaran menggambar teknik dasar kelas $\mathrm{X}$ program keahlian konstruksi batu dan beton SMK Negeri 2 Pematangsiantar ? (2) Apakah pemanfaatan video sebagai media pembelajaran dapat meningkatkan hasil belajar siswa pada mata pelajaran menggambar teknik dasar kelas $X$ program keahlian konstruksi batu dan beton SMK Negeri 2 Pematangsiantar?

Penelitian ini dilakukan bertujuan : (1) Untuk mengetahui peningkatan minat belajar siswapada mata pelajaran menggambar teknik dasar kelas X program keahlian konstruksi batu dan beton SMK Negeri 2 Pematangsiantar dengan menerapkan pemanfaatan video sebagai media pembelajaran. (2) Untuk mengetahui peningkatan hasil belajar siswa pada mata pelajaran menggambar teknik dasar kelas $\mathrm{X}$ program keahlian konstruksi batu dan 


\section{Pemanfaatan Video Sebagai media Pembelajaran Untuk Meningkatkan Minat Belajar dan Hasil Belajar Siswa \\ Pada Mata Pelajaran Menggambar Teknik Dasar Kelas X Program Keahlian Konstruksi Batu dan Beton SMK Negeri 2 Pematang Siantar}

beton SMK Negeri 2 Pematangsiantar dengan menerapkan pemanfaatan video sebagai media pembelajaran.

\section{Landasan Teori}

Minat belajar merupakan masalah yang paling penting di dalam pendidikan, apalagi bila dikaitkan dengan aktivitas seseorang dalam kehidupan sehari-hari. Minat belajar yang ada pada diri seseorang akan memberi gambaran dalam aktivitas untuk mencapai suatu tujuan. Minat belajar merupakan suatu keinginan yang dimiliki oleh seseorang secara sadar. Minat belajar tersebut mendorong seseorang untuk memperoleh subyek khusus, aktifitas, pemahaman, dan keterampilan untuk tujuan perhatian ataupun pencapaian yang diinginkan oleh oleh seseorang tersebut.

Seperti yang dikemukakan oleh H. C. Witherington (1984:135) bahwa: "Minat adalah kesadaran seseorang tentang suatau objek, seseorang, suatu soal atau situasi yang memiliki sangkut paut atau keterikatan dengan dirinya". Dari kutipan ini dapat dijelaskan bahwa pada dasarnya minat harus dipandang sebagai sambutan sadar, kalau tidak demikian minat tidak mempunyai arti sama sekali. Oleh karena itu pengetahuan atau informasi tentang seseorang atau objek harus ada terlebih dahulu daripada minat terhadap sesuatu objek tersebut.

Belajar hakikatnya adalah suatu proses yang ditandai dengan adanya perubahan pada diri seseorang. Perubahan sebagai hasil dari proses belajar dapat diindikasikan dalam berbagai bentuk seperti berubah pengetahuan, pemahaman, sikap dan tingkah laku, kecakapan, keterampilan, dan kemampuan, serta perubahan aspek-aspek yang lain yang ada pada individu yang belajar (Trianto, 2009 : 9).

Dengan berakhirnya suatu proses belajar, maka siswa memperoleh suatu hasil belajar. Hasil belajar merupakan hasil dari suatu interaksi tindak belajar dan tindak mengajar. Dari sisi guru, tindak mengajar diakhiri dengan proses evaluasi hasil belajar. Dari sisi siswa, hasil belajar merupakan berakhirnya penggal dan puncak proses belajar. Hasil belajar dapat dibedakan menjadi 2 yaitu, dampak pengajaran dan dampak pengiring pengajaran adalah hasil yang dapat diukur seperti tertuang dalam angka rapor, angka dalam ijazah atau kemampuan meloncat setelah latihan. Dampak pengiring adalah terapan pengetahuan dan kemampuan di bidang lain, suatu transfer belajar. (Dimyati dan Mudjiono, 2006 : 4-5).

Menurut Kamus Besar Bahasa Indonesia, video merupakan rekaman gambar hidup atau program televisi untuk ditayangkan lewat pesawat televisi, atau dengan kata lain video merupakan tayangan gambar bergerak yang disertai dengan suara. Video sebenarnya berasal dari bahasa Latin, video-vidivisum yang artinya melihat (mempunyai daya penglihatan); dapat melihat. Media video merupakan salah satu jenis media audio visual. Media audio visual adalah media yang mengandalkan indera pendengaran dan indera penglihatan. Media audio visual merupakan salah satu media yang dapat digunakan dalam pembelajaran menyimak. Media ini dapat menambah minat siswa dalam belajar karena siswa dapat menyimak sekaligus melihat gambar.

Video juga bisa dimanfaatkan untuk hampir semua topik, model - model pembelajaran, dan setiap ranah: kognitif, afektif, dan psikomotorik. Pada ranah kognitif, siswa dapat mengobservasi rekreasi dramatis dari kejadian sejarah masa lalu dan rekaman aktual dari peristiwa terkini, karena unsur warna, suara dan gerak di sini mampu membuat karakter berasa lebih hidup.Selain itu dengan melihat video, setelah atau sebelum membaca, dapat memperkuat pemahaman siswa terhadap materi ajar. Pada ranah afektif, video dapat memperkuat siswa dalam merasakan unsur emosi dan penyikapan dari pembelajaran yang efektif. Pada ranah psikomotorik, video memiliki keunggulan dalam memperlihatkan bagaimana sesuatu bekerja, video pembelajaran yang merekam kegiatan motorik/gerak dapat memberikan kesempatan pada siswa untuk mengamati dan mengevaluasi kembali kegiatan tersebut.

\section{Metodologi Penelitian}

Penelitian Tindakan Kelas ( PTK) ini dilaksanakan di SMK Negeri 2 Pematangsiantar, yang beralamat di Jl.Sangnawaluh, Pematangsiantar dan penelitian ini dilaksanakan pada semester ganjil tahun ajaran 2015/2016.

Penelitian ini dilakukan dalam dua siklus, dimana pada setiap siklus tahapan yang dilakukan yaitu, (1) perencanaan, (2) pelaksanaan, (3) pengamatan, (4) refleksi. 
Adapun penjelasan untuk masing-masing tahap tersebut adalah sebagai berikut : (1) Perencanaan Tindakan (Planning) pada tahap ini, peneliti bekerjasama dengan guru mata pelajaran Menggambar Teknik Dasar untuk menemukan pokok bahasan dan menyiapkan perangkat pembelajaran berbentuk silabus dan rencana pelaksanaan pembelajaran (RPP). Kemudian peneliti menyusun tes. Selanjutnya peneliti membuat lembar observasi untuk melihat minat belajar siswa. (2) Pelaksanaan Tindakan (acting) dalam tahap ini, peneliti melakukan pre-tes. Setelah itu, pembelajaran dimulai dengan memperkenalkan materi pelajaran sesuai dengan RPP yang telah disusun sebelumnya dengan menggunakan tindakan penerapan pemanfaatan video sebagai media pembelajaran. Setelah tindakan selesai dilakukan evaluasi belajar dengan memberikan tes pilihan berganda. Pada tahap ini peneliti langsung mengawasi dan membimbing siswa serta memberikan penjelasan yang perlu jika terdapat kesulitan-kesulitan yang dialami siswa dalam proses pembelajaran. (3) Pengamatan (Observing) observasi yang dilakukan merupakan pengamatan terhadap keaktifan siswa selama proses belajar mengajar yang dilakukan oleh rekan peneliti yang mengambil posisi dibelakang siswa, dengan menerapkan pemanfaatan video sebagai media. (4) Refleksi (Reflecting) pada tahap refleksi ini, hasil yang diperoleh dari tahap pelaksanaan tindakan dan observasi dikumpulkan dan dianalisis, sehingga diperoleh kesimpulan dari tindakan yang telah dilakukan.Pada tahapan ini, jika hasil belajar meningkat apabila telah memenuhi Kriteria Ketuntasan Minimum (KKM) $\geq 75$, maka penerapan model pembelajaran LSQ dalam penelitian ini dikatakan mengalami peningkatan atau berhasil. Dan apabila sebaliknya maka ini akan menjadi pertimbangan untuk melakukan siklus selanjutnya.

Tes yang digunakan peneliti adalah tes objektif. Sebelum dilakukan Uji coba instrumen tes objektif ini berjumlah 64 soal dengan empat option, dimana 32 soal untuk siklus I dan 32 soal untuk siklus 2. Namun setelah dilakukan uji coba instrumen, tes objektif berbentuk pilihan berganda menjadi sebanyak 51 soal dengan empat option pilihan, dimana 25 soal untuk siklus I dan 26 soal untuk siklus II, yang digunakan untuk memperoleh data hasil belajar pada kompetensi yang ditentukan.
Adapun teknik analisis untuk hasil belajar siswa adalah sebagai berikut :

Nilai $=$

Berdasarkan Standart Ketuntasan Belajar Minimal (SKBM) yang ditetapkan dalam kompetensi dasar pada penelitian tindakan ini, maka seorang siswa telah dikatakan mencapai kompetensi jika siswa memperoleh skor $\geq 70$ dan tuntas secara klasikal jika seluruh kelas $\geq 75 \%$ diantara siswanya sudah tuntas belajar.

Observasi dipergunakan untuk mengumpulkan data tentang minat belajar siswa dalam proses belajar mengajar dengan menggunakan lembar observasi minat belajar yang sudah disiapkan sehingga pengamat tinggal memberi tanda contreng $(\sqrt{ })$ pada lembar observasi. Dalam hal ini pengamatan dilakukan terhadap proses belajar mengajar yang berlangsung selama kegiatan penelitian. Pengamatan yang digunakan pada penelitian ini menggunakan rentang skor 1 sampai 4 , dan ada 5 indikator yang akan diamati dalam pengamatan minat belajar ini.

\section{Pembahasan dan Hasil Penelitian}

Penelitian ini dilakukan dalam dua siklus dimana pada setiap siklus dilakukan dalam 2 pertemuan. Setiap siklus dilakukan dengan 4 tahapan yaitu: perencanaan (planning), pelaksanaan (acting), pengamatan (observing), dan refleksi (reflecting). Pelaksanaan pembelajaran pada setiap pertemuan meliputi 3 tahapan kegiatan yaitu kegiatan awal, kegiatan inti dan kegiatan penutup. Pembelajaran dilakukan untuk mengetahui nilai minat belajar dan hasil belajar siswa.

Pada pertemuan pertama di siklus I dilakukan pembelajaran dengan menerapkan pemanfaatan video sebagai media pembelajaran sesuai dengan langkah-langkah yang telah direncanakan didalam RPP dan selama pembelajaran berlangsung peneliti mengamati minat belajar siswa. Dan pada pertemuan kedua siklus I, siswa diberikan soal tes yang terdiri dari 25 soal. Setelah itu, Peneliti melakukan analisis data dari pengamatan minat belajar dan nilai hasil belajar yang di peroleh pada siklus I, sebagai dasar peningkatan minat belajar dan hasil belajar siswa pada siklus selanjutnya. Dengan melihat hasil pengamatan minat belajar dan tes hasil belajar siswa pada siklus I. Setelah melaksanakan tindakan siklus I maka diadakan refleksi. Refleksi ini diadakan pada akhir siklus 


\section{Pemanfaatan Video Sebagai media Pembelajaran Untuk Meningkatkan Minat Belajar dan Hasil Belajar Siswa \\ Pada Mata Pelajaran Menggambar Teknik Dasar Kelas X Program Keahlian Konstruksi Batu dan Beton SMK Negeri 2 Pematang Siantar}

I. Dalam pelaksanaannya, refleksi dilakukan bersama guru bidang studi Menggambar Teknik Dasar. Hal ini dilakukan untuk mengkaji pembelajaran yang telah dilakukan pada siklus I. Hasil refleksi mengungkapkan, ternyata terdapat kelemahan - kelemahan diantaranya: (a) Sebagian siswa belum terbiasa dengan kondisi belajar yang mengarah pada pemanfaatan video sebagai media pembelajaran. Hal tersebut disebabkan karena selama ini guru hanya memberi pelajaran dengan metode ceramah lalu memberikan tugas untuk dikerjakan siswa. (b) Sebagian siswa belum memahami pemanfaatan video sebagai media pemebelajaran secara utuh dan menyeluruh. Hal ini dapat dilihat dari hasil penelitian pada siklus I rata-rata minat belajar siswa hanya mencapai 63,09 dengan jumlah siswa yang memiliki kriteria kategori tidak baik (TB) sebesar 35,29\%, kurangbaik (KB) 20,58\%, cukup baik (CB) 26,47\% dan kategori baik (B) $17,65 \%$ sedangkan untuk kategori sangat baik (SB) belum dapat dicapai oleh siswa.

Grafik Histogram Minat Belajar Siswa Siklus

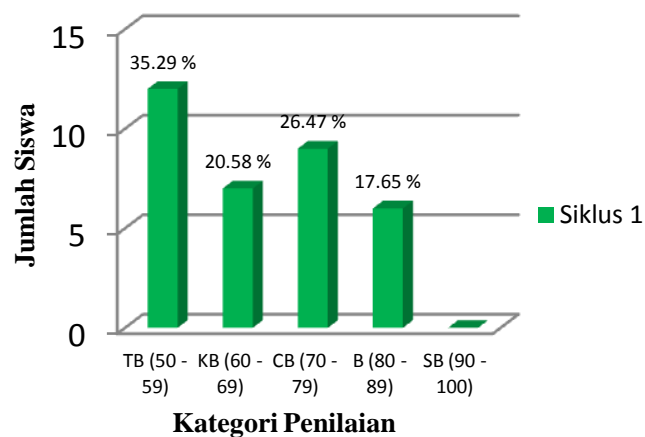

Gambar 1. Grafik Minat belajar siswa siklus I

Ini menunjukkan bahwa belum mengalami peningkatan pada minat belajar siswa. (c) Jumlah siswa yang tuntas belajar sesuai dengan standart nilai KKM adalah 17 orang, dan terdapat 17 siswa yang dinyatakan tidak tuntas dan berdasarkan hal tersebut presentase kelulusan adalah $50 \%$ dengan nilai rata-rata hasil belajar yaitu 72 (belum tuntas).

Berdasarkan analisis proses pelaksanaan pemanfaatan video sebagai media pembelajaran pada siklus I, kegiatan pembelajaran pada siklus I terlihat belum optimal. Berdasarkan temuan-temuan yang telah dipaparkan, peneliti memutuskan melaksanakan tindakan perbaikan guna mencapai ketuntasan belajar siswa. Tindakan perbaikan yang akan diterapkan pada pembelajaran siklus II untuk menutupi kekurangan yang terjadi pada siklus I adalah: (a) Merencanakan ulang proses pembelajaran dengan berdiskusi kepada guru mengenai indikator yang belum tercapai yaitu untuk indikator minat belajar yang belum tercapai adalah sebagian siswa belum berani untuk mengajukan pertanyaan, memberikan pendapat, dan memberikan jawaban. (b) Guru dengan intensif memberi pengertian kepada siswa kondisi belajar dan membantu siswa yang belum memahami langkah-langkah pembelajaran dengan menggunakan pemanfaatan video sebagai media pembelajaran.

Pada pertemuan pertama di siklus II dilakukan pembelajaran dengan menerapkan pemanfaatan video sebagai media pembelajaran sesuai dengan langkah-langkah yang telah direncanakan didalam RPP yang sudah diperbaiki dan selama pembelajaran berlangsung peneliti mengamati minat belajar siswa. Dan pada pertemuan kedua siklus II, siswa diberikan soal tes yang terdiri dari 26 soal. Setelah itu, Peneliti melakukan analisis data dari pengamatan minat belajar dan nilai hasil belajar yang di peroleh pada siklus II, sebagai dasar peningkatan minat belajar siswa dan hasil belajar siswa pada siklus selanjutnya.

Setelah melaksanakan tindakan siklus II, kembali diadakan refleksi bersama guru bidang studi Menggambar Teknik Dasar. Refleksi ini diadakan pada akhir siklus II. Hasil refleksi siklus II mengungkapkan, bahwa kelemahankelemahan yang terjadi pada siklus I dapat diatasi

Setelah dilaksanakan siklus II ternyata terjadi peningkatan terhadap hasil belajar Menggambar Teknik Dasar. Hal ini didapat dari hasil pengamatan minat belajar siswa dan hasil belajar siswa. Dari hasil pengamatan minat belajar siswa didapat nilai rata-rata pada siklus II adalah : 


\section{Grafik Histogram Minat Belajar Siswa Siklus II}

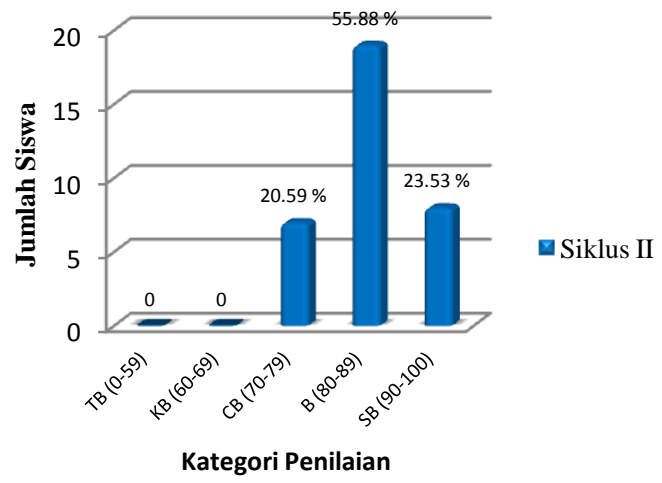

Gambar 2. Grafik Minat belajar siswa siklus II

34 orang siswa memperoleh kategori sangat baik (SB) $23,53 \%$ dengan minat belajar siswa meningkat dari 0 menjadi 8 , kategori baik (B) $55,88 \%$ dengan minat belajar siswa meningkat dari 6 menjadi 19, kategori cukup baik (CB) 20,59\% dengan minat belajar siswa dari 9 menjadi 7, sedangkan untuk kategori tidak baik (TB) dan kurang baik (KB) tidak ada artinya karena seluruh siswa sudah tuntas dalam belajar.

Setelah penerapan metode pemanfaatan video sebagai media pembelajaranselesai dilaksanakan, maka diperoleh hasil belajar siswa yang meningkat dimana kategori Sangat Kompeten (SK) sebesar 29,41\% dari 0

\section{Kesimpulan dan Saran \\ 5.1 Kesimpulan}

Berdasarkan hasil penelitian tindakan kelas (PTK) dapat disimpulkan sebagai berikut : (1) Pemanfaatan video sebagai media pembelajaran dapat meningkatkan hasil minat belajar siswa mengalami peningkatan dari siklus I ke siklus II, dimana minat belajar siswa pada siklus I dengan kategori Tidak Baik (TB) adalah sebanyak 12 orang siswa (35.29\%), kategori Kurang Baik (KB) adalah sebanyak 7 orang siswa (20.59\%), kategori Cukup Baik (CB) sebanyak 9 orang $(26.47 \%)$, kategori Baik (B) sebanyak 6 orang (17.65\%). Sedangkan pada siklus II minat belajar siswa mengalami peningkatan yaitu untuk kategori Tidak Baik (TB) dan Kurang Baik (KB) tidak ada (0\%), kategori Cukup Baik (CB) 7 orang siswa $(20.59 \%)$, kategori Baik (B) 19 orang siswa (55.88\%) dan kategori Sangat Baik (SB) 8 orang siswa (23.53\%). (2) Rata-rata hasil belajar siswa setelah dilakukan penerapan metode pemanfaatan video sebagai media pembelajaran adalah mengalami peningkatan, dimana dari siklus I nilairata-rata hasil belajar siswa adalah 72 meningkat menjadi 85 dengan rata-rata peningkatan penguasaan materi pada siklus I dan siklus II sebesar $18.05 \%$. Dari hasil peningkatan hasil belajar tersebut berarti bahwa penerapan metode pemanfaatan video sebagai media pembelajaran pada mata diklat menggambar teknik dasar mengalami peningkatan. Oleh karena itu, penerapan metode pemanfaatan video sebagai media pembelajaran dapat meningkatkan hasil belajar menggambar teknik dasar siswa kelas $X$ Program Keahlian Konstruksi Batu dan Beton SMK Negeri 2 Pematangsiantar.

\subsection{Saran}

Setelah melihat hasil penelitian, pembahasan, dan kesimpulan maka peneliti memberikan saran sebagai berikut: (1) Diharapkan kepada siswa jurusan konstruksi batu dan beton SMK Negeri 2 Pematangsiantar lebih giat lagi belajar.'(2) Diharapkan kepada guru mata diklat menggambar teknik dasar agar dapat menerapkan metode pemanfaatan video sebagai media pembelajaran untuk meningkatkan minat belajar dan hasil belajar siswa. (3) Diharapkan bagi kepala sekolah untuk dapat lebih memilih media pembelajaran video sebagai metode pembelajaran di kelas. (4) Diharapkan kepada peneliti selanjutnya agar dalam penerapan metode pemanfaatan video sebagai media pembelajaran ini menggunakan standar kompetensi yang berbeda, media belajar yang lengkap sehingga minat belajar dan hasil belajar siswa mengalami peningkatan.

\section{Daftar Pustaka}

Abu Ahmadi \& Supriyono Widodo. 2004. Psikologi Belajar. Jakarta: PT. Rineka Cipta

Agnew, P. W., Kellerman, A. S. \& Meyer, M. J. (1996). Multimedia in the classroom. Boston: Allyn and Bacon

Anderson, Ronald H. 1987. Pemilihan dan Pengembangan Media untuk Pembelajaran. Jakarta : CV Rajawali.

Andi Prastowo. 2012. Panduan Kreatif Membuat Bahan Ajar Inovatif. Yogyakarta: Diva Press. 


\section{Pemanfaatan Video Sebagai media Pembelajaran Untuk Meningkatkan Minat Belajar dan Hasil Belajar Siswa Pada Mata Pelajaran Menggambar Teknik Dasar Kelas X Program Keahlian Konstruksi Batu dan Beton SMK Negeri 2 Pematang Siantar}

Arikunto, S. 2002. Metodologi Penelitian Suatu Pendekatan Proposal. Jakarta: PT. Rineka Cipta

2008. Prosedur Penelitian Suatu Pendekatan Praktek. Jakarta: PT. Rineka Cipta. 1996. Prosedur Penelitian Suatu Pendekatan Praktek. Jakarta: PT. Rineka Cipta. 2006. Prosedur Penelitian Suatu Pendekatan Praktek. Jakarta: Rineka Cipta. 2012. Penelitian Tindakan Kelas. Jakarta: PT. Bumi Aksara.

Arsyad, Azhar. 2002. Media Pembelajaran. Jakarta: PT. Raja Grafindo. 2011. Media Pembelajaran. Jakarta: PT Raja Grafindo Persada.

Daryanto. 1993. Media Visual Untuk Pengajaran Teknik. Bandung: Tarsito.

Mahmud, Dimyati. 1989. Psikologi Pendidikan. Yogjakarta: BPEF.

Dinas Pendidikan Nasional Dirjen Dikdasmen Dikmenjur. 2004. Modul I, II, dan III Kurikulum SMK edisi 2004. Jakarta: Depdiknas.

Hadjar, I. 1996. Dasar-dasar metodologi Penelitian Kuantitatif dalam Pendidikan. Jakarta: Raja Grafindo Persada.

Hari Subekti. 2007. Minat Siswa SMK YKKK 2 Sleman Kelas XI Terhadap Pembelajaran Atletik. Skripsi. Yogyakarta. Fakultas Ilmu Keolahragaan Universitas Negeri Yogyakarta.

Sardiman, AM. 1992. Interaksi dan Motivasi Belajar Mengajar. Jakarta: Balai Pustaka.

Slamento. 2003. Belajar dan Faktor-Faktor Yang Mempengaruhi. Jakarta : Rineka Cipta.

Syah, Muhibbin. 2008. Psikologi Belajar. Jakarta: Raja Grafindo Persada.

Tim, W.R.I. 2001. Bunga Rampai Psikologi dan Pembelajaran. Semarang: Materi Inservice Training KKG-MGMP.

Witherington, H.C. 1984. Tekni-Teknik Belajar dan Mengajar. Bandung: Jemmars. 